The Quarterly Journal of Austrian Economics

Volume 22 | NO. 2 | 218-241 | SuMmer 2019 WWw.QJAE.ORG

\title{
Family Formation, Fertility, and Failure: A Literature Review on Price Increases AND Their Impact ON THE FAMILy Institution
}

\author{
JeFFery Degner*
}

JEL Classification: D10, E34

АвsтRACT: Inflation not only debases the value of currency by lowering purchasing power. It also serves to erode the quantity and quality of marriages while creating distortions in the decision-making processes of those hoping to form marriages and to have children. Furthermore, a loss of purchasing power helps to create relational tension for married couples, contributing to increasing divorce rates throughout the globe. As for the formation of families via marriage, the literature surrounding inflation and the family shows that price increases in higher education and housing both limit the number of first marriages as well raising the average age at which they occur. These phenomena are present in Western democracies, Islamic theocratic regimes, and highly-developed East Asian economies. Rising prices impact already married couples who would pro-create, but decide to accelerate or nearly eliminate child-bearing based on the inflationary environment in which they live. Finally, the literature shows that a loss of purchasing power leads to marital tension and higher rates of divorce. This trend is exhibited all over the world. This relationship occurs across cultural and religious systems as well as differing levels of economic development. While the problem of rising prices is economic in nature, it is shown to have deleterious effects upon the family institution.

* Jeffery Degner (jeff.degner@cornerstone.edu) is Assistant Professor of Economics in the Business Division at Cornerstone University. 


\title{
INTRODUCTION
}

\begin{abstract}
A the centennial gathering of the American Economic AssoA ciation, Dr. Gary Becker addressed those assembled and described a growing awareness of how macroeconomic forces affect the family institution. In his concluding remarks, he noted that the, "evolution of the economy greatly changes the structure and decisions of families." (Becker 1988) The aim of this review is to summarize the literature that describes how a variety of rising prices impact family formation, fertility, and failure. Since family institutions exist throughout the varied cultures of the world, the review will observe the heterogeneity of inflation's impact on the family across cultures and national borders.
\end{abstract}

There are two key distinctions that this writer wishes to articulate. The first is in regards to the philosophical framework and definition of the family institution. In my understanding of the role of family in society, I borrow from the Dutch Calvinist philosopher Abraham Kuyper (while rejecting his views on state intervention into various markets among other views). He describes the family as a divine creation. As such, this 'sovereign sphere' is an institution designed with its own rights, responsibilities, norms, roles, and limits. In addition, the family institution is not subject to the control of other institutions such as ruling authorities, religious institutions, or markets. While at the same time, the family social unit will freely interact with all of the other institutions without being absorbed by or otherwise diminished in its role as the primary way in which children are raised, educated, and socialized. In Kuyper's view, the other divinely inspired institutions such as markets (for goods, services, money creation, and financial assets) and governing authorities also have their own divinely constructed purposes, jurisdiction, and limits.

Our world now represents what happens when mankind rejects the divine order and decides to merge the distinct spheres, regardless of the rationale for doing so. The most important example of such an 'unholy marriage' in our time occurs when the market for money creation is combined with the governing institution. In such instances both of these institutions have already stepped outside of their divinely-ordained spheres of operation. Furthermore, this new, man-made organization necessarily sets itself up against the 
other institutions that choose to retain their intended form and function. As such, this man-made entity will inevitably infringe on the proper operations of the other sovereign spheres. This viewpoint provides a narrative for the corrosive effects of modern central banking cartels upon the family institution. In Kuyper's view, "surely, to centralize all power in the one central government is to violate the ordinances that God has given for nations and families. It destroys the natural divisions that give a nation vitality, and thus destroys the energy of the individual life-spheres and of the individual persons." (Van Dyke 2015)

This observation is quite meaningful in our time as we observe both Central Bank inflation and the 'deinstitutionalization' (Cherlin 2004) of the family and of marriage throughout the world. Altered family structures and decisions are seen in the delay of family formation and by increasing divorce rates across the globe. Perhaps unwittingly, Cherlin affirmed that a growing disregard for Kuyper's definition of the family institution has emerged in $20^{\text {th }}$ century America for the very reasons that Kuyper describes. In light of this deinstitutionalization, this literature review seeks to describe how researchers have linked declining purchasing power to the crumbling institution of marriage.

The second point of clarification is that the writer of this review defines inflation as any increase in the supply of money and credit. I reject the notion of 'inflation' as an increase in government-measured price levels. In most cases, the literature does not adopt this writer's definition. Therefore, when some writers refer to "inflation", I will refer to "price increases". The first reason for this clarification is based on Richard Cantillon's observation that price increases are not simultaneous, universal, nor do they occur by the same degree in all places after monetary injections have occurred. (Murphy 1989) In addition, the writer discards the mainstream use of the term 'inflation' on the grounds that it is considered to be synonymous to the US Bureau of Labor Statistics' Consumer Price Index. I reject the CPI and commonly used term 'inflation' precisely because it does not reflect the experience of rising prices within households, across income levels, races, or even genders. (Michael 1975, Hobijn and Lagakos 2003, Armantier et al. 2012, Sequino and Heintz 2012, Bryan and Venkatu 2002) 
To provide an overview of the literature on family formation, I first begin with the economic theory of family formation articulated by Gary Becker. In 1974, he described marriage as a process of "Positive Assortive Mating" where potential spouses seek to improve their overall utility as compared to the utility held by remaining single. The existence of mate selection processes by no means requires one to dismiss marriage as a divinely created institution. The fact that men and women select partners to improve overall utility does not require that the institution is therefore simply a man-made institution. Just as a person may select a seat on a airplane based on their subjective values that account for prices, comfort and other factors does not mean that they are responsible for the construction of the plane or for the physical laws that govern its operation. Likewise, in mate-seeking, the desire to gain additional marginal utility in a state of marriage, potential partners consider factors such as IQ, education level, height, ethnicity and more, while not altering the fundamental design of marriage itself.

Recent scholarship has revealed that in the US, price increases and the ensuing distress borrowing by young people is positively correlated to the average age of first marriage. (Bosick and Estacion 2014, Gicheva 2016) To be more precise, education-based debt levels of the potential spouse have been shown to have a negative impact on the positive assortive mating that Becker describes. These high debt levels are associated with inflation in higher education tuit $\neg \neg$ ion. However, these high debt levels are more consistent with the educational attainment of middle and upper middle-class American youths who can afford to delay the necessity of work.

Among these more affluent young people, it is obvious that not every couple wishes to live together or to have children. The literature shows that among those with higher incomes and higher levels of educational attainment, many couples avoid traditional marriage and choose to cohabitate simply because they have different costs in view than their poor counterparts. The literature affirms that these couples are waiting to reach financial milestones, not in terms of nominal cash holdings or income, but in terms of real asset and property accumulation. The achievement of such goals is made more difficult with a lack of purchasing power. (Smock et al. 2005) All told, the literature paints a picture wherein inflationary pressure across geographic, racial, and educational descriptors is 
linked to delayed marriage formation and non-formation in the case of cohabitating couples.

In the case of the poor in the US, rising prices for the goods that they consume have been shown to increase criminality among single males. Males who have resorted to more lucrative criminal activity and the incarceration that often ensues has, resulted in low marriageability status across cohorts in the United States. Another consequence of male criminality is that there are increasing levels of fatherless children throughout racial groups, as these men are viewed as reproductive partners, but not as traditional husbands or fathers. (Rosenfeld et al. 2018) This situation further erodes the family institution when coupled with the wage inflation that has been more prominent for females in the US, which leads many women (even those with low labor productivity) to eschew husbands as providers in exchange for provision from the state, their own wages, or older family members. (Schneider et al. 2018)

The presence of increasing prices has also been shown to impact the fertility rates of married couples over time and in different cultural and economic settings. Robert T. Michael observed that wealthy and poor households experience price increases differently in the modern US economy. Since this is the case, it follows that the poor and the wealthy would approach fertility decisions differently as well. (Michael 1979) This observation foreshadowed Caldwell's work in international family economics, which asserted that families in low-income countries respond to price increases by growing the number of children they bring into the world. They decide to do so because their offspring represent net positive income flows and because the children can contribute to overall family wealth with their low-skilled labor. Conversely, in developed nations, the increasingly high price of educating children for modern economic life leads families to have fewer children, as each child produces negative income flows during their years under their parents' roofs. (Caldwell 1983)

In more recent research, Kaplan suggested an update to Caldwell's view by introducing different measures for ascertaining intergenerational wealth flows. Specifically, there is a call to recognize the fact that underdeveloped economies often measure wealth in terms of commodity acquisition rather than nominal monetary amounts. 
(Kaplan 1994) When considering the body of literature on how higher prices effects fertility, it is shown that a lack of wealth across time, culture, and economic standing all produce fertility rates that are distortions from a natural state of reproductive supply and demand within households. Ultimately, developed nations tend to have lower fertility rates, leading some to fall short of zero population growth, while developing nations still struggle with the challenges of young, booming populations. When families in these poor nations also experience price increases, fertility rates are also shown to increase. The literature also demonstrates that there is a negative relationship between price increases and fertility in developed nations.

Across the world, families also dissolve under the pressure of escalating prices. The literature examining US divorce rates since 1929 has shown that during periods of large price increases that there is a robustly positive relationship to marriage dissolution. (Nunley and Zietz 2012) This relationship was most powerfully illustrated throughout the 1960s and all the way through the Vietnam Era. The escalating prices caused by 'Great Society' legislation such as Medicare and Medicaid, coupled with the massive expenditures on the war in Vietnam both occurred during this period and represented a shift of real resources from American households to the welfare state and to war-making. These macroeconomic realities left the already married with a loss of purchasing power and all of the relational strains that come along with it. Some literature has asserted that this ongoing increase in the divorce rates in the US, and particularly the high divorce rates of the 1970s, were caused by the adoption of no-fault divorce law. (Peters 1993, Friedberg 1998, Rogers et al. 1999) However, Wolfers finds that while these changes in the legal environment did have an initially positive but weak correlation to divorce rates, these effects did not persist over time. (Wolfers 2006)

Meanwhile, in the UK, a similar conclusion was reached by research which showed that the liberalization of divorce law simply lowered the cost of the divorce transaction, ensuring the end of marriages that were already "on the rocks", while having no impact in the long-run trend. (Smith 1997) Throughout the European continent, divorce rates have also climbed substantially in the post-WWII era. Some have indicated that the rise of the welfare state (itself a part of 
the inflationary regime) has encouraged both lower rates of family formation and more frequent divorce. (Balestrino et al. 2013)

In southwestern Asia, price increases in the Iranian housing sector and for dowry payments have been shown to drive increased divorce rates from 1982 through 2010. (Farzanegan and Gholipour 2015) The authors note that this is a particularly troubling social trend in such a conservative Islamic state. Also, in Pakistan, connections have been drawn between price increases for the goods that households typically consume to increases in domestic violence and female spousal abuse, clinical depression among both men and women, and understandably, an increasing divorce rate. (Khanam et al. 2015)

Across the planet, central bank inflation has led to price increases in the markets for goods that are important to families everywhere. There is little doubt that local customs surrounding family formation and expectations for familial behavior can produce a wide variety of responses to the loss of purchasing power. In order to capture more of those specific examples, this review will now turn to a more precise look at the realities of family life under the pressure of elevated prices.

\section{PRICE INCREASES AND FAMILY FORMATION}

In 1960, the average age for first family formation for US females was 20.1 years and 22.2 for males. Forty years later, the first marriage for US women had jumped to 24.4 and to 26.1 for men. (Schoen and Canudas-Romo 2005) Even greater change has been afoot in England and Wales during the same time period. There, the average age of first marriage for women went from 21.0 to 26.3 and from 23.4 to 28.3 for men. At the same time these researchers note the increase in co-habitation as an alternative arrangement for adults living together, leading to a decline in the real prevalence of marriage over time.

Recent research in the US regarding the later age of first marriage has yielded findings stating that the rising cost of higher education and the accompanying debt load held by both men and women is positively correlated to the average age of first marriage. (Addo et al. 2018) More specifically, Addo's research shows that the greater 
the student loan debt, the more likely young men and women are to cohabitate and for longer as opposed to entering a marriage relationship. Furthermore, with more education, the expectations of young people are that they would marry one with similar educational status. (Becker 1974) In addition, it has been shown that MBA students not only raise their age of first marriage, but that they decrease the likelihood of ever being married at all. (Gicheva 2016) This relationship is stronger among female MBAs than for their male counterparts. Research has found that for every $\$ 1,000$ in student loan debt that women carry, they reduce their odds of first marriage by 2 percent per month after undergraduate graduation. (Bozick and Estacion 2014) Although massive higher education debt loads are peculiar to the US it is plausible that if significantly negative net worth is carried into the housing market, that a person carrying the debt will seem less marriageable. (Bleemer et al. 2014) Alongside such credit-based challenges is the lack of affordable housing, a phenomenon that is hardly unique to the US. In Great Britain price increases in the housing market have also kept young people at home (and single) longer than in past decades, thus delaying the age of first marriage there as well. (Ermisch and Francesconi 2003)

The marked increases in East Asian first marriage age have also been driven by housing prices. In Singapore, qualitative studies on the attitudes of young singles make it clear that the male is under considerable social pressure from family and their potential spouse to acquire a flat. (Jones et al. 2012, Quah 2008) Delays in first marriage in Eastern Asia demonstrate similar trends as those in the US but to an even higher degree. In Japan the average age of first marriage for men has risen from 26.9 in 1970 to 30.5 in 2010. Their female counterparts have seen a change in this statistic go from 24.2 to 28.8. (Raymo et al. 2015) The pattern is similar in South Korea and Taiwan. The question addressed here is whether price increases have anything to do with this phenomenon. The literature does indicate that the later age for family formation in East Asia is largely driven by rising prices. These prices include the housing, education, food, and energy sectors. It is apparent to researchers that these increasing costs of living do have a positive relationship to age at first marriage. (Park and Sandefur 2005) These rising prices are coupled with cultural expectations of aspirational consumption which also contribute to first marriage delays. (Mu 
and Xie 2014) Other features that delay first marriages in East Asia include extended family expectations of co-residence, educational mismatches in the marriage market, and extended family expectations regarding fertility. Despite these nuances, the common theme of price increases and their positive correlation to age at first marriage is present both in the East and the West.

\section{PRICE INCREASES AND FAMILY FERTILITY}

When Robert T. Michael observed that poor families within the US experienced price increases differently than the wealthy, and that their experiences were worse than the reported CPI measurements, it became clear that the poor would behave differently than the wealthy in the face of rising prices than those of higher income levels. (Michael 1979) This reality inside the US makes Caldwell's views on family behavior in underdeveloped economies versus industrialized nations all the more understandable. In his theory of wealth flows, it was explained that parents in underdeveloped parts of the world would respond to their lack of labor productivity and purchasing power with a set of choices that was distinct from their counterparts in the industrialized nations of the world. He observed that because low-skilled labor and wages were attainable by young children, their parents would seek their income generating efforts to combat the family's lack of wealth. With this reasoning, parents would not only expect their children to work at an early age, but they themselves would respond to these conditions by having even more children, thus increasing the fertility per female in the underdeveloped world. In addition, the US welfare system creates incentives for unwed mothers to have more children and not to educate them beyond their years of free public education. By funding higher education, children would begin represent a negative net income flow. Thus, unwed and poor mothers are presented with an incentive structure that encourages non-education and the immediate (though short-term) benefits of children working in low-skilled labor markets in order to contribute to increased family income. (Caldwell 1983)

When it comes to the middle-class and wealthy in the United States, declining fertility rates have not only been linked to the reasoning provided by family economists like Caldwell, but 
healthcare economists have weighed in as well. The Journal of Medical Economics contends that the delay in first marriage and family formation contributes to overall lifetime fertility decline. With the increase in age of first marriage, and subsequent first conception within marriage, fertility rates are lower among women who have their first child later in life. This observation may seem as obvious as it is trivial. However, if it is clear that economic realities impact physiological outcomes, it is easy to see why some would describe increasing prices and the subsequent loss of fertility as a public health concern. (Tannus and Dahan 2018, Sunderam et al. 2015)

Simply put, the literature demonstrates a chain of events where the increases in education costs and housing prices delay first marriage, first childbirth, and ultimately lead to diminished fertility. To quantify the decline in fertility in the US, the average number of children per woman has plummeted from 3.65 in 1960 to 1.84 in 2015. (FRED 2019) Further study on the connection between rising prices and falling fertility suggests that parents sense a moral obligation to refrain from having children during periods of money and credit expansion via central bank policy (Abo-Zaid 2013) In this line of reasoning, parents observe climbing prices and recognize that providing education, nutrition, and general care will be more difficult as they lose purchasing power. Furthermore, this loss of purchasing power leads many married couples to seek more than one income, making child-rearing more difficult as the couple demonstrates a subjective preference for time working over time spent raising children. Earlier literature defends a model where this outcome means that the children of these parents will decrease the next generation's labor supply, driving output per capita higher for women who will then substitute child-bearing for income earning. (Galor and Weil 1996) This theoretical connection, however, has not been found robust by some (Jones et al. 2012) who assert that the same would be true for males whose greater earning power would enable women to resume more traditional child-rearing roles.

Innovative research from England and Wales has emerged as researchers have sought to distinguish between the fertility response to home price increases between renters and existing home owners. The findings are complementary to those in the US for renters as higher home prices deter would-be owners from 
having more children. This negative relationship between housing prices and fertility does not hold for British homeowners from 1995 to 2008. (Washbrook 2018) Although there is a positive relationship between home prices and fertility for homeowners, this effect was found to be temporary. This finding is not necessarily contrary to economic theory because homeowners believe they will acquire more wealth in the future through the sale of that home. It is plausible that this anticipated increase in wealth makes them feel as though they are able to support more children. This explanation of homeowner behavior is consistent with earlier studies in the US where renters have a 2.4 percent decline in fertility for every $\$ 10,000$ in average home prices, while the homeowners respond with a 1 percent increase in fertility. (Dettling and Kearney 2011) If we use Becker's reasoning to shed some light on this outcome, it is reasonable to posit that for renters, the cost a future home will be too great to afford the cost of the delivery and care of an additional child. However, the reasoning could be reversed for families who currently own a home. They may look at the potential proceeds of the sale of their home as being a greater financial benefit allowing them to have another child and perhaps the purchase of a new home with more space to accommodate those additional children.

It has been found that for East Asian families, the negative relationship between price increases and fertility are not only present but have even stronger effects than they do in the West. Japan has been at or below replacement rates since 1957. South Korea has experienced a rapid decline in fertility since the 1970s, and Taiwan's fertility has reached an extremely low 0.9 children per mother in 2010. (Raymo et al. 2015) Once again, these lower lifetime fertility rates are associated with higher age for a mother's first marriage and first birth, spurred by the high costs of education and housing. In fact, the average age of first delivery in Japan reached 29.3 years of age in 2010. In the same year, the mean age at first birth reached 30.1 in South Korea and 29.6 in Taiwan. Other literature on East Asia explicitly refers to Becker's model of fertility behavior when studying the impact of housing prices in Hong Kong upon fertility rates from 1971 until 2005. (Yi and Zhang 2009) Using a cointegration analysis, researchers found that for every 1 percent increase in housing prices there was a statistically significant negative relationship in fertility rates of 0.45 percent. Further testing revealed 
that housing price inflation can account for about 65 percent of the fertility decrease in Hong Kong since the 1970s.

The general pattern of the literature paints a picture of middle-class and wealthy families in developed nations who reduce their fertility in response to rising costs of housing and education. In pre-modern economies as well as among the poor in developed nations with sizeable welfare states, the literature points to a pattern where parents increase their fertility rates in order to benefit from the net positive income that children can produce. This is especially the case in low-skilled labor markets within those nations. Parents in those situations will often remove their children from schooling as the opportunity costs to the family's standard of living is too great. (Rosenzweig and Evenson 1977)

\section{PRICE INCREASES AND FAMILY FAILURE}

When substantial price increases occur in the markets for goods and services demanded by married couples, the returns on staying married are diminished. This finding by Nunley and Zietz is clarified by observing the dramatic rise in the US new divorce rate through the 1960s and 1970s. When the stagflation era ended in the early 1980s, they find that a slowing of price level increases also contributed to a decline in the rate of new divorces which continued through 2005. (Nunley and Zeist 2012) The literature also shows that when unexpected macroeconomic shocks occur, changes such as increasing prices or increasing unemployment also produce higher rates of divorce. (Becker et al. 1977) The causal link between the rising price of consumption goods and divorce begins when spouses have to increase the quantity of labor supplied to maintain the same levels of spending and leisure as they had previously enjoyed. This then leads to a decrease in the time spent on leisure and household production, leading to relational tension and conflict. Since potential wage increases do not keep pace with price increases, there are worsening financial and relational returns on the marriage relationship. (Christiano et al. 2001)

Some literature has emphasized the increases in women's educational attainment and their higher labor force participation rate as leading causes of increased US divorce rates in the 1960s and 70s, 
but these findings are not without controversy. (Lombardo 1999) This dispute arises because others have found that it is the higher divorce rate which drives an increase in the labor force participation rate among women who have already received higher amounts of education in the preceding decades. (Bremmer and Kesselring 2004, Spitze and South 1986, Mincer 1984) This approach suggests a feedback loop where more divorce leads to more female labor force participation, which leads to greater earning power, and eventually more divorce. Yet another explanation for the higher divorce rates in the $60 \mathrm{~s}$ and $70 \mathrm{~s}$ is that rising prices required both spouses to work outside the home. This macroeconomic shock required women to begin accelerating their entry into the workforce, which created the relational tensions already described. The resulting large-scale female entry into the workforce disrupted familial harmony, childrearing patterns, and the domestic division of labor. This narrative is substantiated by Nunley and Zietz's empirical methodology which produced results showing a positive relationship between inflation rates, nominal GDP growth rates, increasing amounts of women's educational attainment, and divorce rates. (Nunley and Zietz 2012) However, this study does not establish links between those 3 determinants which leads to opportunities for further study. One important caveat to this explanation is that it does not include the liberalization of divorce laws. While some have suggested that this is a driving force in the high divorce rates, (Friedberg 1988) Nunley and Zietz exclude this variable due to the literature that shows that the advent of no-fault divorce law in the US has a small and short-lived positive impact on increasing divorce rates, but no impact on long-term frequency of divorce. (Wolfers 2006)

In the British context, the literature also seeks to establish the multivariate causes of divorce including the legal framework within the UK as well as macroeconomic triggers. The literature notes that when reforms in divorce law were introduced in the European context, divorce rates were already climbing and the supply of these reforms merely met the demands for innovation and lower costs for divorce. In other words, the reforms were a response to rather than a cause of rising divorce rates. (Becker 1993, Michael 1988) Over the course of the post WWII period, the UK has experienced similar trends in the divorce rates as those in the US. The British had rapid increases in rates of divorce in the 1960s and 70s and found that 
rates were lower from the rise of Thatcher onwards. (Smith 1997) In Britain, Smith reaches similar conclusions as Wolfers did in the US. While there is a positive correlation between divorce liberalization and the divorce rate, the correlation is weak and temporary. However, a lack of literature is clear in the case of identifying the impact of price increases on divorce rates in Great Britain. This lack of research may be the result of a lack of concern over the issue in general as societal values regarding divorce have moved from viewing divorce as a taboo to viewing it with indifference.

In the Middle East, the issue of divorce is hardly viewed lightly and is even considered a public health risk due to its negative impact on children and women. (Barikani et al. 2012) A significant body of research has come from Iran in recent years. When examining the causes for a rising divorce rate in the Islamic Republic, both women and men cite economic dependence upon other family members for maintaining an acceptable standard of living as a leading cause of divorce. Fifty eight percent of men seeking divorce in this literature cite economic dependency upon extended family members as a driving force in the dissolution of their marriages while 49 percent of women say the same. Furthermore, 53 percent of divorced females specifically cited their former husband's inability to pay for the rising cost of living as a prominent factor in their divorces. Additional research from Iran indicates that from 2002 through 2010, Iran had reached the highest divorce rate in the Islamic world. Furthermore, the price of housing both for renters and owners was directly linked to marital tension and divorce. (Farzanegan and Gholipour 2015) In addition, rising unemployment rates and increases in both public and private spending on education were positively correlated to this change in divorce rates. In a unique urban setting, Tehran was found to have thousands of vacant investment residences thus reducing the supply and driving rental prices to very high levels. Farzanegan and Gholipour are careful to point out that when there are sudden and unexpected surges in housing prices, there are even stronger positive effects on the divorce rate. In an interesting note on education spending in Iran, these researchers explain (like Caldwell) that increasing prices for education also suggest lower fertility rates among married couples. The lower number of children in turn diminishes the social pressure for families to 
remain together. In other words, families with fewer children have a higher likelihood of divorce than those who have offspring.

A compelling cultural idiosyncrasy in Iran that has been shown to drive increasing divorce rates is the practice of 'Mehrieh' or a dowry. This payment is traditionally required to be delivered in gold coins. (Farzanegan and Gholipour 2018) The price of a gold as a reliable measure of a loss of overall purchasing power is one of the most commonly accepted premises in monetary economic theory. The Mehrieh asserts the legal right of the wife to request payment in gold jewelry or coin at the time of marriage or after the marriage has already begun. The ever-increasing nominal price of gold places great financial strain on the male partner, thus producing further marital tension. The existence of this arrangement has also been found to cause an increasing age of marriage formation by an average of 3 additional years from 1986-2011. The cultural purpose of the Mehrieh is to act as a form of self-insurance for the wife and her family. It us used to cushion the financial blow of a divorce in order to protect women from economic ruin after a divorce. The Mehrieh this lowers the cost of divorce for women, making it less likely that women will remain in tense marriages. In addition, young brides who are aware of the diminishing purchasing power of currency versus gold actually plan for an early divorce in order to collect the Mehrieh as an appreciating asset in order to facilitate their own independent living arrangement. Although this narrative may present a system of perverse incentives to the western mind, it does illustrate the similarity of effects on families due to falling purchasing power against real assets like gold or housing and the increasing divorce rates to match. (Conger et al. 1990, Jensen and Smith 1990, Amato and Beattie 2011, Harknett and Schneider 2012, Dehghanpisheh 2014)

Eastern Asia, like the Near East and West, has also experienced rising divorce rates and the literature points to similar causes as those in other parts of the world. The general literature surrounding East Asian marriage points out that marriage as an institution has become increasingly less attractive for both those who would be married and for those who are already in marriages and that macroeconomic factors play a significant in the decaying esteem of marriage. (Bumpass et al. 2009, Rindfuss et al. 2004) While many values of East Asian marriage remain intact, some researchers show 
that it has adopted western values as well. (Cai 2010, Thornton et al. 2012) In light of these changes, projections show that 20 percent of South Korean marriages are expected to fail by 2023. (Park and Raymo 2013) Nearly $1 / 3$ of Japanese marriages are expected to end in divorce. (Raymo et al. 2004) One important contrast between those who divorce in East Asia is that divorce is clearly more prevalent among lower income couples than for higher income families. This narrative is similar to the one in Iran where young and relatively low-income families have difficulty affording suitable housing and the relational strain placed on marriages has a corrosive effect on their longevity. These lower income families are also less educated and as such researchers have shown that there is a strong negative relationship between education level (and thus earning and purchasing power) and divorce rates. (Chen 2012)

\section{CONCLUSION}

Across the globe, family formation, fertility, and failure are all impacted by rising prices. In the US, the age of first marriage is higher than ever due to high education costs that are manifest in increasing debt loads for young adults. This reality means that their incomes are redirected to debt repayment, making already increasing housing prices even harder to afford. Throughout Europe and East Asia housing affordability is also leading young people to delay their first marriage as well. Across the globe, these increasing prices are making cohabitation more financially sensible than marriage.

The literature shows that fertility decisions are distorted in the developing world and for the poor in developed countries. A pattern emerges that when prices rise, parents have more children as they are viewed as adding to family assets. Families make these reproductive decisions and at later ages may pull children out of school due to their ability to earn incomes through their low-skilled labor in order to combat price increases. This keeps families from making investments towards their children's education and eventually, a higher standard of living. Meantime, in the developed world, wealthier parents choose to have fewer children in response to increasing costs for housing and for educating their offspring. The body of literature concurs with much of Caldwell's theory on intergenerational wealth flows. 
Research from across the globe shows that when married couples are met with falling purchasing power, marital tensions rise. In the developed world these couples who face rising prices have less motivation to stay married as the average number of children is already relatively low. In the underdeveloped world, the literature shows that the relational tension brought on by rising prices is exacerbated by cultural expectations of male provision and extended family pressures. This is a recipe for higher divorce rates even among some of the most traditional societies.

All of these realities show a body of literature that affirm Kuyper's vision of the family institution being under stress from man-made institutions such as central banks who produce debased currency and easy credit. This state of affairs leads to the detriment of families as they see the value of their savings and purchasing power evaporate for the things that are most important to maintaining a suitable standard of living. The literature described in this review paints a picture of the 'deinstitutionalization' of marriage and family that Cherlin described. In seeking a common thread among the erosion in the quantity and quality of marriages throughout the world, it is the loss of purchasing power brought on by central bank money supply inflation which drives people to avoid marriage across the world through delay, cohabitation and divorce. Children in poor nations suffer under inflation as well because their parents require them to work so that the family might survive. Meanwhile, in the developed world, children see less of their parents as two incomes are often necessary to make ends meet, while their parents' marriages are under threat of divorce due to the relational and financial difficulties brought on by rising prices.

There is room in the body of literature for a stronger statement on the strength of the correlation between rising prices in the categories that are important to family formation. More work remains to establish how tuition rate increases in the US lead to higher ages of first marriage. There is also an opportunity to describe the distinctions between fertility decisions in the developed and developing economies of the world. Research could focus on price increases for childcare, education, food, energy, and housing for their impact on fertility rates in both types of economies. The literature on housing and gold prices increases and divorce has received a very promising set of studies from Iran and researchers 
could attempt the same type of examination in other nations as well. While several attempts have been made to describe liberal divorce laws and changing norms regarding sexuality and views on cohabitation there is also room for more specific links to discover which prices in the economy have the most powerful effect on marriages that end in divorce.

In the end, we observe that a divinely-created institution can have its definition and even its existence malformed and eventually crushed under the weight of man-made institutions like central banking cartels. This description of the deinstitutionalization of the family and marriage should warrant serious attention from Austro-libertarian thinkers. The simple reason for this is that marriage and family are distinctly non-state institutions that have always been capable of providing wealth, order, and continuity, within a framework of peaceful and voluntary cooperation. Therefore, family holds a unique place among institutions as a bulwark against the deleterious effects of the welfare state. As such, it is an institution worth defending and strengthening as the Austro-libertarian school aims to abolish man-made central banks and replace them with free-market money production and consumption.

\section{REFERENCES}

Abo-Zaid, Salem. 2013. "The Effects of Macroeconomic Aggregates on Fertility Decisions: Theory and Evidence from US Annual Data." Accessed December 21, 2018. https://www.aeaweb.org/aea/2014conference/program/retrieve.php?pdfid=709.

Addo, Fenaba R., Jason N. Houle, and Sharon Sassler. 2018. “The Changing Nature of the Association Between Student Loan Debt and Marital Behavior in Young Adulthood." Journal of Family and Economic Issues 40, no. 1: 86-101.

Amato, Paul R., and Brett Beattie. 2011. "Does the Unemployment Rate Affect the Divorce Rate? An Analysis of State Data 1960-2005." Social Science Research 40, no. 3: 705-15.

Armantier, Olivier, Scott Nelson, Giorgio Topa, Wilbert Van Der Klaauw, and Basit Zafar. 2012. "The Price Is Right: Updating of Inflation Expectations in a Randomized Price Information Experiment." FRB 
of New York Staff Report No. 543. https://papers.ssrn.com/sol3/papers. cfm?abstract_id=1995811

Balestrino, Alessandro, Cinzia Ciardi, and Claudio Mammini. 2013. "On the Causes and Consequences of Divorce." Journal of Socio-Economics 45, no. 1: 1-9.

Barikani, Ameneh, Sarichlow Mohamad Ebrahim, and Mohammadi Navid. 2012. "The Cause of Divorce among Men and Women Referred to Marriage and Legal Office in Qazvin, Iran." Global Journal of Health Science 4, no. 5 .

Becker, Gary S. 1974. "A Theory of Marriage: Part 2." Journal of Political Economy 82, no. 2: S11-S26.

_ 1993. "Nobel Lecture: The Economic Way of Looking at Behavior." Journal of Political Economy 101, no. 3: 385-409.

Becker, Gary S., Elisabeth M. Landes, and Robert T. Michael. 1977. "An Economic Analysis of Marital Instability." Journal of Political Economy 85, no. 6: $1141-87$.

Becker, Gary S., and Kevin M. Murphy. 1988. "The Family and the State." Journal of Law and Economics 31, no. 1: 1-18.

Bleemer, Zachary, Meta Brown, Donghoon Lee, and Wilbert Van Der Klaauw. 2014. "Debt, Jobs, or Housing: What's Keeping Millennials at Home?" SSRN Electronic Journal no. 700: 1-49.

Bozick, Robert, and Angela Estacion. 2014. “Do Student Loans Delay Marriage? Debt Repayment and Family Formation in Young Adulthood." Demographic Research 30, no. 69: 1865-91.

Bremmer, Dale, and Randy Kesselring. 2004. “Divorce and Female Labor Force Participation: Evidence from Times-series Data and Cointegration." Atlantic Economic Journal 32, no. 3: 175-90.

Bryan, Michael F., and Guhan Venkatu. 2002. "The Curiously Different Inflation Perspectives of Men and Women." Federal Reserve Bank of Cleveland Economic Commentary.

Bumpass, L. L., R. R. Rindfuss, M. K. Choe, and N. O. Tsuya. 2009. "The Institutional Context of Low Fertility: The Case of Japan." Accessed December 22, 2018. https://www.tandfonline.com/doi/ abs/10.1080/17441730903351479. 
Cai, Yong. 2010. “China's Below-Replacement Fertility: Government Policy or Socioeconomic Development?" Population and Development Review 36, no. 3: 419-40.

Caldwell, John C. 1983. "Theory of Fertility Decline." Journal of Marriage and the Family 45, no. 1: 238.

Chen, Wan-Chi. 2012. “The Changing Pattern of Educational Differentials in Divorce in the Context of Gender Egalitarianization: The Case of Taiwan." Population Research and Policy Review 31, no. 6: 831-53.

Cherlin, Andrew J. 2004. "The Deinstitutionalization of American Marriage." Journal of Marriage and Family 66, no. 4: 848-61.

Christiano, Lawrence, Martin Eichenbaum, and Charles Evans. 2001. "Nominal Rigidities and the Dynamic Effects of a Shock to Monetary Policy." Journal of Political Economy 113, no. 1: 1-45.

Conger, Rand D., Glen H. Elder, Frederick O. Lorenz, Katherine J. Conger, Ronald L. Simons, Les B. Whitbeck, Shirley Huck, and Janet N. Melby. 1990. "Linking Economic Hardship to Marital Quality and Instability." Journal of Marriage and the Family 52, no. 3: 643-56.

Dehghanpisheh, Babak. 2014. "Rise in Divorce in Iran Linked to Shift in Status of Women." Reuters. Accessed December 22, 2018. https:// www.reuters.com/article/us-iran-divorce-iduskcn0ib0gq20141022.

Dettling, Lisa J., and Melissa Schettini. Kearney. 2011. House Prices and Birth Rates: The Impact of the Real Estate Market on the Decision to Have a Baby. Cambridge, Mass: National Bureau of Economic Research.

Ermisch, John F., and Marco Francesconi. 2003. "Family Structure and Children's Achievements." Pp. 151-72 in Family, Household and Work, ed. K. F. Zimmerman and M. Vogler. London: Springer Verlag.

Farzanegan, Mohammad Reza, and Hassan Fereidouni Gholipour. 2015. "Divorce and the Cost of Housing: Evidence from Iran." Review of Economics of the Household 14, no. 4: 1029-54.

Farzanegan, Mohammad Reza, and Hassan F. Gholipour. 2018. “Does Gold Price Matter for Divorce Rate in Iran?" Journal of Family and Economic Issues 39, no. 4: 588-99.

FRED. 2018. "Fertility Rate, Total for the United States." Federal Reserve Economic Data. Accessed December 20, 2018. https://fred.stlouisfed. org/series/SPDYNTFRTINUSA. 
Friedberg, Leora. 1998. “Did Unilateral Divorce Raise Divorce Rates? Evidence from Panel Data." American Economic Review 88, no. 3: 608-27.

Gicheva, Dora. 2016. "Student Loans or Marriage? A Look at the Highly Educated." Economics of Education Review 53, no. 1: 207-16.

Harknett, Kristen, and Daniel Schneider. 2012. "Is a Bad Economy Good for Marriage? The Relationship between Macroeconomic Conditions and Marital Stability from 1998-2009." The National Poverty Center Working Paper Series. \#12-06.

Hobijn, Bart, and David Lagakos. 2003. "Inflation Inequality in the United States." Review of Income and Wealth 51, no. 4: 581-606.

Jensen, Peter, and Nina Smith. 1990. "Unemployment and Marital Dissolution." Journal of Population Economics 3, no. 3: 215-29.

Jones, G.W., Z. Yanxia, P. C. Zhi. 2012. "Understanding High Levels of Singlehood in Singapore." Journal of Comparative Family Studies 43, no. 5: 731-50

Kaplan, Hillard. 1994. "Evolutionary and Wealth Flows Theories of Fertility: Empirical Tests and New Models." Population and Development Review 20, no. 4: 753-91.

Khanam, Farida, Syed S. Pirzada, and Shafufta Nasreen. 2015. "Impact of Inflation on Economic Growth in Pakistan." International Journal of Science and Research 4, no. 11: 1091-96.

Lombard, Karen V. 1999. “Women's Rising Market Opportunities and Increased Labor Force Participation." Economic Inquiry 37, no. 2: 195-212.

Michael, Robert T. 1975. "Variation Across Household in the Rate of Inflation." Journal of Money, Credit, and Banking 11, no. 1: 32-46.

— 1988. "Why Did the US Divorce Rate Double Within a Decade?" Research in Population Economics 6, no. 1: 367-99.

Mincer, Jacob. 1984. "Inter-Country Comparisons of Labor Force Trends and of Related Developments: An Overview." Journal of Labor Economics 3, no. 1: 1-32.

$\mathrm{Mu}$, Zheng, and Yu Xie. 2014. "Marital Age Homogamy in China: A Reversal of Trend in the Reform Era?" Social Science Research 44, no. 1: 141-57. 
Murphy, Antoin E. 1989. "The Publication of the Essai in 1755." Richard Cantillon: Entrepreneur and Economist. Oxford: Oxford University Press.

Nunley, John M., and Joachim Zietz. 2012. “The Long-Run Impact of Age Demographics on the US Divorce Rate." The American Economist 57, no. 1: 65-77.

Park, Hyunjoon, and Gary D. Sandefur. "Transition to Adulthood in Japan and Korea: An Overview." Sociological Studies of Children and Youth 10, no. 1: 43-73.

Park, Hyunjoon, and James M. Raymo. 2013. “Divorce in Korea: Trends and Educational Differentials." Journal of Marriage and Family 75, no. 1: 110-26.

Peters, Elizabeth H. 1993. "The Importance of Financial Considerations in Divorce Decisions." Economic Inquiry 31, no. 1: 71-86.

Quah, Stella. 2008. Families in Asia. Singapore: Eastern University Press

Raymo, James M., Larry Bumpass, and Miho Iwasawa. 2004. "Marital Dissolution in Japan." Demographic Research 11, no. 14: 395-420.

Raymo, James M., Hyunjoon Park, Yu Xie, and Wei-Jun Jean Yeung. 2015. "Marriage and Family in East Asia: Continuity and Change." Annual Review of Sociology 41, no. 1: 471-92.

Rindfuss, Ronald R., Larry L. Bumpass, Minja Kim Choe, and Noriko O. Tsuya. 2004. "Social Networks and Family Change in Japan." American Sociological Review 69, no. 6: 838-61.

Rodgers, Joseph Lee, Paul A. Nakonezny, and Robert D. Shull. 1999. “Did No-Fault Divorce Legislation Matter? Definitely Yes and Sometimes No." Journal of Marriage and the Family 61, no. 3: 803-09.

Rosenfeld, Richard, Matt Vogel, and Timothy Mccuddy. 2018. "Crime and Inflation in U. S. Cities." Journal of Quantitative Criminology 35, no. 1: 195-210.

Rosenzweig, Mark R., and Robert Evenson. 1977. "Fertility, Schooling, and the Economic Contribution of Children of Rural India: An Econometric Analysis." Econometrica 45, no. 5: 1065-79.

Schneider, Daniel, Kristen Harknett, and Matthew Stimpson. 2018. "What Explains the Decline in First Marriage in the United States? Evidence 
from the Panel Study of Income Dynamics, 1969 to 2013." Journal of Marriage and Family 80, no. 4: 791-811.

Schoen, Robert, and Vladimir Canudas-Romo. 2005. “Timing Effects on First Marriage: Twentieth-century Experience in England and Wales and the USA." Population Studies 59, no. 2: 135-46.

Seguino, Stephanie, and James Heintz. 2012. "Monetary Tightening and the Dynamics of US Race and Gender Stratification." American Journal of Economics and Sociology 71, no. 3: 603-38.

Smith, Ian. 1997. "Explaining the Growth of Divorce in Great Britain." Scottish Journal of Political Economy 44, no. 5: 519-43.

Smock, P. J., Manning, W. D., and Porter, M. 2005. “Everything's There Except Money": How Money Shapes Decisions to Marry among Cohabitors. Journal of Marriage and Family 67, no. 3: 680-96.

Spitze, Glenna, and Scott J. South. 1985. “Women's Employment, Time Expenditure, and Divorce." Journal of Family Issues 6, no. 3: 307-29.

Sunderam, Saswati, Dmitry M. Kissin, Sara B. Crawford, Suzanne G. Folger, Sheree L. Boulet, Lee Warner, and Wanda D. Barfield. 2018. "Assisted Reproductive Technology Surveillance-United States, 2015." MMWR Surveillance Summaries 67, no. 3: 1-28.

Tannus, Samer, and Michael H. Dahan. 2018. "Decrease in American Birth Rates Makes It Imperative for the United States to Implement State Mandated Fertility Coverage." Journal of Medical Economics 22, no. 3: 252-53.

Thornton, Arland, Georgina Binstock, Kathryn M. Yount, Mohammad Jalal Abbasi-Shavazi, Dirgha Ghimire, and Yu Xie. 2012. "International Fertility Change: New Data and Insights from the Developmental Idealism Framework." Demography 49, no. 2: 677-98.

Van Dyke, Harry. 2015. Our Program: A Christian Political Manifesto by Abraham Kuyper. Bellingham, Wash.: Lexham Press.

Washbrook, E. 2014. "Do High Prices Deter Fertility: Evidence from England and Wales." October 30. Accessed December 21, 2018. http:// www.bristol.ac.uk/cmm/research/housing/publications/do-high-prices-deter-fertility.html.

Weil, David N., and Obed Galor. 1993. "The Gender Gap, Fertility, and Growth." American Economic Review 86, no. 3: 374-87. 
Wolfers, Justin. 2006. “Did Unilateral Divorce Laws Raise Divorce Rates? A Reconciliation and New Results." American Economic Review 96, no. 5: 1802-20.

Yi, Junjian, and Junsen Zhang. 2009. "The Effect of House Price on Fertility: Evidence from Hong Kong." Economic Inquiry 48, no. 3: 635-50. 